\title{
ROLA DZIEDZICTWA WIELOKULTUROWEGO W ŚWIADOMOŚCI MIEJSKICH AKTORÓW. PRZYKLAD GDAŃSKA I WROCŁAWIA
}

\section{Streszczenie}

Celem artykułu jest próba przedstawienia konceptualnych ram, w jakich przebiega obecnie dyskurs związany z wielokulturowością Gdańska i Wrocławia, który nadaje znaczenia miejscom, zdarzeniom, osobom, stanom rzeczy, porządkując pamięć i kształtując tożsamość. W tym celu skoncentrujemy się na analizie sposobu prezentowania przez ekspertów oraz zwykłych aktorów-laików wzorców tożsamościowych tych dwóch miast $\mathrm{z}$ wielokulturowym kapitałem założycielskim. Przywołamy w tym celu niektóre założenia wielowymiarowej koncepcji nowoczesności, w tym teorii strukturacji Anthony'ego Giddensa, w której wyróżnia on wiedzę dyskursywną, czyli taką którą jej posiadacze potrafią ująć w słowa, i praktyczną, ważną w działaniu, ale trudną do werbalizacji. Podejście to wiąże się z przesunięciem akcentu w stronę działających i refleksyjnych jednostek, a także - w naszym przekonaniu - umożliwia pokazanie problemu wielokulturowości w kontekście dyskursywnych i praktycznych kodów konstytutywnych dla tożsamości obu miast. Podstawą empiryczną analizy są wywiady częściowo ustrukturyzowane z ekspertami przeprowadzone w Gdańsku i Wrocławiu oraz wywiady kwestionariuszowe z mieszkańcami tych miast. Główna oś rozważań dotyczy

* Dr hab. prof. PG, Wydział Architektury; e-mail: mdym@pg.edu.pl

** Dr hab. prof. UWr, Instytut Socjologii; e-mail: katarzyna.kajdanek@uwr.edu.pl 
zróżnicowania modeli refleksyjności zakorzenionych w praktykach społecznych, potencjale produkcji i reprodukcji miejskości w analizowanym zakresie wielokulturowości.

Słowa kluczowe: wielokulturowość, tożsamość, dziedzictwo, Gdańsk, Wrocław

\section{WPROWADZENIE}

Od kilku dekad ważne miejsce w dyskursie socjologicznym zajmuje kwestia swoistego napięcia między zjawiskiem „ukulturowienia” miast poprzez wykorzystywanie dziedzictwa przeszłości, które ma szczególną wartość kulturową dla obydwu miast i które podlega współczesnej interpretacji, nadając tym miejscom nowe znaczenia. Jest to między innymi efekt rozwoju rynku dóbr symbolicznych, procesu indywidualizacji jednostek, możliwości korzystania z nowych technologii i nowych wzorów konsumpcji. W wielu miastach toczy się walka o akumulację znaków dystynkcji i kolektywnego kapitału symbolicznego. W społeczeństwie pomasowym każdy chce mieć prawo do wyboru i konsumpcji jakiegoś kulturowego artefaktu, może być to również potrzeba identyfikacji z nim choćby na chwilę [Krzysztofek 2005]. „Jeśli przyjąć, iż mamy do czynienia z globalizacją różnorodności w przestrzeni miejskiej, to znaczy, że wygrają tylko te kultury, którym uda się przetłumaczyć swe walory na spektakl i dobrze sprzedający się produkt rynkowy..." [Krzysztofek 2005: 49]. Ideały miejskiej tożsamości ustępują konsumpcjonizmowi, turyzmowi i przemysłowi kultury. $Z$ jednej strony występuje duże zainteresowanie innością, pozytywną waloryzacją różnorodnych form i zasobów (społecznych, kulturowych, materialnych), z drugiej zaś daje się zauważyć brak kompetencji do wielokulturowego dialogu. Takie dopasowywanie kultury do potrzeb rynku stwarza nowe wyzwania i prowokuje do pytania, czy wielokulturowość w Gdańsku i Wrocławiu będzie kategorią trwałą, czy też przeminie wraz z modą na dekonstrukcję kultury, polegającą na braniu z niej tylko tych elementów, które w danym momencie można przekuć w produkt rynkowy.

Przyjęcie założenia, że mamy do czynienia z globalizacją różnorodności w przestrzeniach miast, dialektyką indygenizacji i kosmopolityzmu, może oznaczać, że coraz więcej miejsca w dyskusji o przyszłości miast zajmie kwestia nowych obszarów miejskości z charakterystycznym dla paradygmatu wielokulturowości nurtem otwartości, przygodności i tymczasowości [por. Haydn, Temel 2006; Beck, Grande 2009]. Globalna wykładnia świata narzuca bowiem typ miejskości, w którym z coraz większą łatwością przychodzi stylizacja na 
autentyczność, tradycję czy wspólnotę wyobrażoną [Dymnicka 2017: 19]. Współcześnie „synkretyzm i parodystyczna inwencja stają się regułą, a nie wyjątkiem, w zurbanizowanym, wielonarodowym świecie instytucjonalnej tymczasowości. [...] w takim świecie coraz trudniejszą rzeczą staje się połączenie ludzkiej tożsamości i znaczenia ze spójną «kulturą czy językiem»" [Clifford 1992: 11, cyt. za: Burszta 1998: 172].

Trudno w tej sytuacji o jednoznaczną interpretację złożoności zjawiska wielokulturowości, które zawsze funkcjonuje odmiennie, w zależności od kontekstu historycznego, polityk miejskich i dominujących postaw w poszczególnych miastach. W ostatnich latach w narracjach o tożsamości Gdańska i Wrocławia na szczególną uwagę zasługuje obecność elementów dziedzictwa jeszcze do niedawna uznawanego za nie swoje, obce kulturowo. Chodzi w nich o to, ,aby różne dyskursy, identyfikacje, tożsamości, a w konsekwencji i «interesy» (niemieckie, danzigerskie, polskie, autochtoniczne, kaszubskie, kresowe, mennonickie, ewangelickie, żydowskie etc.) mogły się uzupełniać, uczestnicząc «na równi» w konstruowaniu tożsamości współczesnego miasta" [Obracht-Prondzyński 2011: 25].

Należy podkreślić, że posługiwanie się pojęciem wielokulturowości wymaga za każdym razem rozróżnienia definicyjnego, bowiem może być ono odnoszone do odmiennych zjawisk społecznych i kulturowych [szerzej: Golka 2010; Sadowski 2011]. Jak pisze Jeffrey C. Alexander [2010: 149]: „Każdy okres historyczny wymaga narracji, która definiuje jego przeszłość w kategoriach teraźniejszości oraz sugeruje przyszłość, która jest od nich zasadniczo różna i, zwykle, «jeszcze lepsza» niż czasy współczesne". Poczucie niestabilności, przejściowości (transitoriness) świata destabilizuje dawne modele, wprowadzając nowe mity do teorii społecznej. W wyłaniającej się fazie neomodernizacyjnej bądź teorii rekonwergencji daje się dostrzec takie formy narracyjne, które łączą się z różnymi okresami historycznymi i konceptualizacjami problemu. Procesy te możemy zaobserwować w przestrzeni analizowanych miast, które przekonująco obrazują, jak współcześni mieszkańcy dzielą świat na sferę sacrum i profanum, manewrując pomiędzy jedną a drugą z potrzeby identyfikacji, przynależności i tożsamości. Pamięć, tożsamość i przestrzeń tworzą krąg zdarzeń i zjawisk wzajemnie się dopełniających - jak pokazują ostatnie badania nad Gdańskiem, Gliwicami i Wrocławiem [szerzej: Bierwiaczonek, Dymnicka, Kajdanek, Nawrocki 2017].

Przestrzeń miejska już w samej substancjalności stwarza inspirujące okoliczności do nowego rozumienia tożsamości oraz wielokulturowości. Terminy te, jak zauważają Ulrich Beck i Edgar Grande [2009], nie powinny już wymagać poświęcania odrębności, zaznaczania i odznaczania przestrzeni jako „swojej” i „obcej”. Chodziłoby raczej o poszukiwanie sposobów, by uczynić przestrzeń 
miejską „uniwersalnie respektowaną” [Beck, Grande 2009: 44]. Pomocne w tej perspektywie - ze względu na erę różnorodności (języków, stylów życia, wzorów kulturowych, porządków gospodarczych, historycznych etc.) - wydaje się pojmowanie kwestii odmienności/różnicy jako niewyczerpanego źródła kosmopolitycznej samowiedzy. Odnosi się to nie tylko do państw, lecz także do miast, bowiem wielokulturowość przejawia się najwyraźniej właśnie w ich obrębie. Jest widoczna z powodu nieuchronności dziejowej towarzyszącej procesom historycznym i modernizacyjnym. Tych drugich nie da się zamknać wyłącznie w epoce nowożytnej, ale należy dostrzegać je również w odległych dziejach urbanizmu [szerzej: Golka 2010]. W istnienie i rozwój miast od samego początku wpisana była tendencja do różnicowania, przekształcania, nawarstwiania. Procesy te przyczyniły się do powstania miejskiego stylu życia, którego zasadniczą cechą jest różnorodność. Ujawnia się ona z całą mocą w przestrzeniach publicznych. Krystalizują się w nich tożsamości zbiorowe oraz poczucie przynależności do miejsc nagromadzenia symboli wspólnej historii, do których odwołują się jednostkowe i kolektywne identyfikacje. „Stosunek publiczności do architektury stanowi zawsze bardzo czuły wskaźnik jej stosunku do współczesności [...]. Przeszłość jest idealną przestrzenią, w której można szukać schronienia przed teraźniejszością" [Czumalo 2012: 48]. Obecność w niej różnych kultur umocowana jest zarówno w substracie materialnym, jak i w praktykach rytualnych, w języku. Jak pisze Zygmunt Bauman [2003: 224]: „Bez względu na to, jak układają się losy miast i w jak drastyczny sposób może się zmieniać przez lata oraz stulecia ich struktura przestrzenna, ich wygląd i styl, jedno pozostaje w nich niezmienne: miasta są przestrzeniami, w których obcy sobie ludzie żyją tuż obok siebie".

Mnogość perspektyw przedstawiania wielokulturowości uświadamia nam złożoność i problematyczność tego pojęcia. Wielokulturowość jest też czymś nieodwołalnym [por. np. Krajewski 1997; Welsh 2004; Sadowski 2011]; stanowi zarówno element wzbogacający przestrzeń, jak i źródło konfliktów, napięć i sporów. Jak piszą Anna Śliz i Marek Szczepański [2011: 11]: „To zinstytucjonalizowane na zasadach demokratycznych współżycie w określonej przestrzeni społecznej jednostek, wspólnot i innych form zbiorowości społecznych, cechujących się wyartykułowaną społecznie tożsamością kulturową". Wielokulturowość można ujmować, zwracając uwagę na jej różnorodne sensy. Skupiając się na podmiotach wielokulturowości, dostrzegamy przede wszystkim specyfikę grup tworzących wielokulturowe zbiorowości. Jednak choć w tradycyjnych analizach za nośniki wielokulturowości uznawano grupy etniczne i narodowe, to współcześnie dostrzega się znaczenie grup nieetnicznych, także wytwarzających różnice kulturowe. Mnogość obliczy wielokulturowości została podkreślona w propozycji 
odróżnienia jej wymiaru etnicznego i nieetnicznego [Mucha 1999]. Pierwszy odnosi się do społeczeństw, których fundamentem ,jest długie trwanie porządku kulturowego w obrębie zróżnicowanych etnicznie grup" [Śliz, Szczepański 2011: 19], czyli skuteczne oddziaływanie mechanizmów międzypokoleniowego przekazu systemów wartości grup społecznych w danym społeczeństwie. Drugi pozostaje typowy dla odpolitycznionej kultury kształtowanej przez rynek i popyt na przejawy wielokulturowości. W tym ujęciu ,wielokulturowość sprowadza się do prostego nasycenia przestrzeni społecznej symbolami, identyfikującymi kulturowe zróżnicowanie" [Śliz, Szczepański 2011: 19]. Przykładowymi manifestacjami urynkowionej wielokulturowości są restauracje etniczne lub festiwale „inności”, niemające istotnego związku z kulturami rzeczywiście funkcjonującymi w danym miejscu. Problem relatywizacji wzorów kulturowych, które miałyby być podstawą wielokulturowości, rozstrzyga Andrzej Szahaj [2010], wskazując zgodnie z paradygmatem społecznego konstruowania rzeczywistości społecznej, że uznanie odrębności określonych kultur przez członków danej zbiorowości decyduje o ich rzeczywistym istnieniu.

Agregacja zbioru cech podobnych umożliwia rozpoznawanie przez kolejne pokolenia mieszkańców znaków ciągłości i zarazem odrębności. W dyskursie narracyjnym ważne miejsce przypada jednak tym elementom (przedmiotom, symbolom, metaforom, mitom), które wzmacniają poczucie przynależności do miasta. „Gdzieś w tle muszą być oczywiście jakieś fakty, ale nie o nie przede wszystkim chodzi, tylko o to, jaka ich część zostaje zapamiętana i wyposażona w znaczenie" [Szacki 2001: 53]. Wszystko to sprawia, że ludzie potrzebują historii, ale niekoniecznie takich, które opowiadałyby im, jak było naprawdę. Społeczne zapotrzebowanie na historię ma bowiem charakter praktyczny [Szacki 2001: 53]. Ta pragmatyka prowokuje do zadawania pytań: Czyja kultura będzie oficjalna, a czyja pozostanie w ukryciu, zapomnieniu? Czyje głosy powinny być zapamiętane, a czyje zapomniane? Jakie obrazy życia społecznego powinny być wykorzystane, a jakie pozostać we mgle niepamięci? Są to pytania o dziedzictwo i tożsamość [Kowalski 2013: 10-11]. Dziedzictwo, jak pisze z kolei Pierre Nora [2010: 235], ,zakończyło epokę historii, narodu i zabytków na rzecz epoki pamięci, społeczności i tożsamości”. Skierowanie uwagi na pojęcie dziedzictwa wydaje się uzasadnione w kontekście rozważań o wielokulturowości, gdyż pozwala uchwycić warunki, w jakich kształtowała się przestrzeń dla refleksji. Odnosi się to w szczególnym stopniu do relacji ze światem zewnętrznym, innymi ludźmi i obcymi kulturami, w związku z czym narzuca się pojęcie wielokulturowości pozostającej niejako w „tożsamościowej podświadomości”. W naszych rozważaniach wyjdziemy od wielokulturowości jako tygla (melting-pot), aby 
przez zakorzenienie przejść do umiarkowanej wielokulturowości, w której brane jest pod uwagę bardziej uznanie różnic niż tolerancja.

W niektórych polskich miastach prowadzona jest już polityka zachęcająca do zajęcia się procesami tożsamościowego otwierania się na nie swoje dziedzictwo, lecz bez żadnych obietnic ani zobowiązań. Wydaje się, że w większości przypadków mamy jednak do czynienia z dyskursywnym uznaniem obecności innych kultur, wpisującym się dość powierzchownie w ideologię/politykę wielokulturowości jako pewnego typu otwartości na świat. Wielokulturowość, pomijając spory, modele i debaty, łączy kwestie kulturowe ze społecznymi. Stwarza perspektywę otwarcia na nie swoje dziedzictwo, jest wyzwaniem dla miast, w których wciąż toczy się spór o przeszłość i o pamięć. Niektórzy badacze tej problematyki zauważają, że szczególny rodzaj otwartości na różnice przypomina targ, na którym można kupić i sprzedać „,inność”. Zróżnicowanie wielokulturowe, nawet jeśli istnieje tylko w pamięci historycznej, może stać się elementem powierzchownej polityki ze skłonnością do redukcji i upraszczania. W skrajnej postaci różnorodność jako wartość kosmopolityczna przejawia się w oderwaniu od kultury i miejsca, które ją symbolizują [por. Binnie, Holloway, Millington, Young 2006].

Zagadnienie wielokulturowości pozostaje zatem w istotnym związku z tożsamością odnoszącą się do czasu i miejsca, miasta i mieszkańców, a więc oznacza konstruowanie sensu na podstawie pewnego zbioru atrybutów kulturowych, którym przyznaje się pierwszeństwo przed innymi źródłami sensu. We współczesnych miastach obserwujemy coraz częściej różnorodność światów społecznych i nowych przestrzeni miejskich, które odznaczają się takimi cechami, jak fragmentacja, ostro zarysowane granice i wątła nić porozumienia z innymi podobnymi światami. Symboliczna identyfikacja zachodzi wtedy, gdy w konstruowaniu tożsamości jako budulec wykorzystuje się materiały pochodzące z historii, pamięci zbiorowej, materialnej tkanki architektonicznej i urbanistycznej. Michel Wieviorka [2011: 122] zauważa, że tożsamości miejskie, takie jak się nam prezentują dzisiaj, ,są w dużej mierze odmienne od tego, jak mogły wyglądać w epoce, w której dotknęły je krzywdy historyczne. Ale równocześnie mogą w sposób mniej bądź bardziej uprawomocniony powoływać się na pewną ciagłość". Ich konstruowanie zachodzi zawsze w ramach społecznych i przestrzennych. Na ten aspekt pojęcia tożsamości zwracają uwagę Mirosława Marody i Anna Giza-Poleszczuk [2004: 168], zauważając, że: „[...] skoro kolektywne procesy konstruowania rzeczywistości obejmują nie tylko jej klasyfikowanie, lecz także jej interpretowanie, to właśnie owe różnice interpretacji stanowią kluczową linię oddzielającą nie tylko in-group od out-groups, «nasz świat» od 
«ich świata», lecz również to, co ma sens i to, co jest tego sensu pozbawione". Podkreślmy także, że dyskusja o wielokulturowych miastach jako źródłach nowych tożsamości nie wykracza poza ramy dyskursywne. W miastach takich jak Gdańsk i Wrocław mamy do czynienia z „etnifikacją” przestrzeni publicznej ograniczającą się do pejzażu kulinarnego. W gruncie rzeczy, podążając tropem Richarda Sennetta, można zauważyć, że istnieje coraz większa pokusa unikania potencjalnie wzbogacających kontaktów z odmiennością. Zgodnie z przyjętym przez nas w artykule punktem widzenia kulturowe atrybuty pochodzą $\mathrm{z}$ wielu opowieści i mają wiele historii, a tożsamość społeczno-przestrzenna to także cechy genealogiczne oraz stosunek mieszkańców do symboliki (wielo)kulturowej. Stosunek ten wiąże się z istotną kompetencją, którą Giddens określa jako refleksyjność, czyli zdolność do krytycznego myślenia o sobie samym [Giddens 2003; 2001].

Rozważanie kwestii potencjału (wielo)kulturowego Gdańska i Wrocławia rodzi pytania, które stanowią podstawę dylematów współczesności: Kim są inni dla nas? Kim my jesteśmy w oczach innych? Wymaga to wejścia na poziom samoświadomości, który wyrasta z procesów charakterystycznych dla społeczeństwa ponowoczesnego i zawiera pewien potencjał nowego otwarcia się na kultury jako elementy dziedzictwa nie swojego, a co za tym idzie - przyjęcia założenia o metodologicznym kosmopolityzmie [Beck 2016].

Kluczowym elementem tych rozważań jest świadomość, że możemy w sposób podmiotowy, a nie tylko przedmiotowy, włączać dziedzictwo wielokulturowe w refleksję o współczesnych tożsamościach. W dyskusji na ten temat przydatne są argumenty, które przedstawia Giddens, przykładając wielką wagę do procesów i negocjacji znaczeń. Na fundamencie podmiotowości buduje refleksję o płynnym i nieustannym oddziaływaniu wiedzy badaczy, ekspertów oraz wiedzy, jaką kierują się członkowie społeczeństwa. Zdaniem brytyjskiego teoretyka podwójna hermeneutyka nadaje dyskusjom o życiu społecznym i jego regułach nowy wymiar. Warto zauważyć, że odrzuca on rozumienie struktury świata społecznego w kategoriach rzeczywistości sui generis. Na pierwszy plan wysuwa w swojej koncepcji dualnej struktury (the duality of structure), po pierwsze, rolę wiedzy i świadomości dyskursywnej, czyli takiej, którą ,jej posiadacze potrafią ująć w słowa, objaśniając to, co robią" (odpowiada to temu, co aktorzy biorący udział w naszym badaniu potrafią wyrazić na temat warunków społecznych, których wielokulturowość jest istotnym aspektem), po drugie, świadomość praktyczną (czyli to, co aktorzy biorący udział w badaniu wykorzystują w codziennych praktykach, ale czego nie potrafią opisać w kategoriach dyskursywnych) i, po trzecie, nieświadomość (czyli sposoby działania bez dostępu do pamięci i wiedzy o ich 
złożonych uwarunkowaniach). Wiedza praktyczna nie jest łatwa do werbalizacji. Pozostaje trzeci poziom wiedzy, związany z podświadomością, dający poczucie ontologicznego bezpieczeństwa.

Podążając tropem Giddensa, możemy powiedzieć, że rosnąca rola refleksyjności w czasach późnej nowoczesności stwarza nowe płaszczyzny dyskusji na temat miasta $\mathrm{i}$ jego roli $\mathrm{w}$ procesie budowania tożsamości jednostkowej i społecznej. Celem naszego artykułu jest próba pokazania ram interpretacyjnych i konceptualnych, w jakich przebiega obecnie większość dyskursów dotyczących roli wielokulturowego dziedzictwa w kształtowaniu tożsamości Gdańska i Wrocławia. Zauważając, że wielokulturowość (z całą różnorodnością zakodowanych w niej znaczeń oraz w sytuacji odmiennych sposobów wykorzystywania jej dla celów polityki miejskiej) pełni coraz istotniejszą funkcję miastotwórczą, stawiamy sobie za cel ukazanie złożoności i zróżnicowania procesu włączania dziedzictwa kulturowego badanych miast do struktury ich miejskich tożsamości.

Skoncentrujemy się na analizie sposobu prezentowania przez ekspertów oraz zwykłych aktorów-laików wzorców tożsamościowych tych dwóch miast z wielokulturowym kapitałem założycielskim.

\section{PRZESTRZENIE DLA DYSKUSJI O WIELOKULTUROWOŚCI. ESTETYKA KOSMOPOLITYZMU}

W procesie opróżniania czasu i przestrzeni, który jest kluczowy dla głównych czynników nowoczesności, szczególne miejsce zajmują systemy eksperckie, które wiążą czas i przestrzeń za pomocą symboli, kodów kulturowych, konstrukcji mitotwórczych i innego typu przekazów. Dla naszego kontekstu istotne jest wspomniane we wprowadzeniu pojęcie kosmopolityzmu, którego istota leży w tym - jak piszą Beck i Grande [2009: 43] - by „postrzegać Innych jako różnych oraz jako równych”. „Nie chcemy być od nikogo zależni, w sposób naturalny każdy chciałby się pozbyć takiej zależności. Powstają nowe mury, nowe granice, a mimo to obcego nie da się wykluczyć" [Beck 2016: 51]. Kosmopolityzacja zachodzi na wielu poziomach, również - a może przede wszystkim - widać ją w miejskich przestrzeniach. Pociagga za sobą krytykę metodologicznego nacjonalizmu. Wbrew konwencjonalnym twierdzeniom nie istnieje tylko jeden prawdziwy kosmopolityzm. Przy całej swojej pogardzie do miejsca jest on wyrazem specyficznie europejskiego uniwersalizmu filozoficznego, manifestacja idei greckich i oświeceniowych. Podobna postawa sprowadza się do uznania istnienia wielu kosmopolityzmów, które niekiedy, jak w przypadku Gdańska, odgrywają ważną rolę w całym procesie budowania tożsamości. Gdańsk buduje 
swoją politykę otwartości na estetyce kosmopolityzmu, zakorzenionej głównie w przeszłości, lecz z coraz wyraźniejszymi odniesieniami do czasów obecnych. Każdy z nas ma wiele korzeni i wiele związków i tym samym nie musi dokonywać wyboru jednej perspektywy ze szkodą dla drugiej - pisze Bruce Robbins [1998]. Jak zauważa Beck [2016: 52], nie żyjemy w czasach kosmopolityzmu, lecz kosmopolityzacji - ,[t]a druga dotyczy faktów, dotyczy świata, w którym powiązanie stwarza coś na kształt odgórnej inkluzywności”. Owa postawa odnosi się dzisiaj do całych miast. I chociaż przypisuje się jej z gruntu idealistyczne cechy związane z etyką, a nie codzienną rzeczywistością, to trudno nie dostrzec znaczenia kosmopolityzacji w zglobalizowanym świecie. Wrocławska polityka otwartości zaprzęga idee kosmopolityzmu, kierując się względami utylitarnymi, opisywanymi co prawda w kategoriach takich wartości jak tolerancja i otwartość, ale obliczonymi na osiąganie efektów ekonomicznych, uzyskiwanych dzięki przyciaganiu do miasta zagranicznych studentów, specjalistów pracujących w międzynarodowych korporacjach oraz inwestorów z innych krajów. Wyraźnie daje się zauważyć, jak niewiele wysiłków władz jest nakierowanych na oswajanie mieszkańców z wielokulturową przeszłością (te zabiegi są zindywidualizowane, sprywatyzowane, niszowe), a jak wiele się robi, by tę wynalezioną wielokulturowość komunikować językiem marketingu na zewnątrz.

Przestrzeń dyskusji o wielokulturowości badanych miast jest składnikiem sfery publicznej, w której ucierają się postawy wobec Innych. Rozważane dylematy można sprowadzić do zasadniczego pytania o to, kim są dla nas Inni i czy musimy (możemy? chcemy?) ,ścierpieć się obok siebie”, włączając się w relacje podporządkowane „kulturze darów”. W dyskusji biorą udział, z odmiennym zaangażowaniem i motywacjami, różni aktorzy miejscy, których można opisać, wykorzystując omówione wcześniej kategorie refleksyjności - rozumianej jako zauważanie i otwieranie się na wielokulturowość będącą elementem dziedzictwa nie swojego.

Ta sfera dyskusji jest przedmiotem szczególnego oddziaływania tych aktorów miejskich, którzy odgrywają rolę liderów opinii, oraz obszarem ścierania się różnych interpretacji. Wydaje się, że wciąż obowiązuje model funkcjonowania sfery publicznej, w której opinie liderów przenikają do szerszych kręgów społecznych i tam dopiero są przetwarzane, poddawane refleksji albo, przeciwnie, pomijane, by uniknąć konieczności podważania i kwestionowania „tego, co oczywiste”, lub wręcz spychane do nieświadomości.

Debata o wielokulturowości jako istotnym aspekcie tożsamości toczy się w Gdańsku od dawna. Towarzyszą jej rozważania o ideach i wartościach, które odżyły po II wojnie światowej. Ostatnie lata XVIII wieku uznano za cezurę 
kończącą czasy, z których czerpano inspiracje w projektach odbudowy miasta po zniszczeniach wojennych. „Złoty wiek” stał się podstawą decyzji projektowych. W polityce pamięci prowadzonej przez władze Gdańska i władze reprezentujące państwa, do których miasto należało, istotnym zjawiskiem było usuwanie jednoznacznie identyfikowalnych niechcianych symboli. Gdańsk po II wojnie światowej został odbudowany przez społeczność napływową, która nie utożsamiała się z jego tradycją i historią, wyczuwała jednak przynależność do wspólnego kręgu kultury zachodniej. Gdańsk stał się miejscem pamięci dla tych, którzy musieli go opuścić, lub dla urodzonych tutaj po wojnie i szukających swoich korzeni. Ożywiona przestrzeń wraz z rzeczami i ich specyficznym uporządkowaniem stanowiła bądź to podporę, bądź to przeszkodę dla pamięci. Materialne ślady niemieckości miasta starano się zatrzeć różnymi sposobami. Z przestrzeni publicznej usuwane były niemieckie napisy, zarówno inskrypcje na zabytkowych budowlach, jak i nazwy sklepów czy reklamy. Historyzujące i secesyjne budynki burzono, gdyż nie odpowiadały nowym poglądom estetycznym, a także kojarzyły się z czasami pruskimi. Dziś w Gdańsku trwa proces przywracania pamięci i pokazywania nacji współtworzących gdańskie tożsamości, przy jednoczesnym podkreślaniu, że dyskusję należy poszerzać nie tylko o kolejne tematy, lecz także o nowych aktorów. Jest to zgodne ze współczesnym nurtem rozwoju miasta, w którym rozwój urbanistyczny stał się jednym z głównych procesów wytwarzania przestrzeni miejskiej. Refleksyjność gdańszczan, którą można uznać za rozwiniętą i skłaniającą do dyskusji o wielokulturowości, pozwala im dostrzec, że wytwarzana przez uczestników opowieść jest tylko jedną z możliwych. W owym procesie nadawania mocy sprawczej mieszkańcom ujawnia się dość szerokie pole manewru prowadzące do względnej niezależności od sił politycznych i rynkowych. W sercu tych oczekiwań znajduje się chęć negocjacji i renegocjacji sytuacji, zdarzeń i interakcji pomiędzy zmieniającymi się zespołami aktorów.

Z kolei istotnymi cechami wrocławskiej debaty o wielokulturowej tożsamości miasta są: jej mała intensywność, niska temperatura i niewielkie zainteresowanie, wynikające, po pierwsze, z dość powszechnej akceptacji oficjalnej narracji zaproponowanej przez władze, po drugie, z dość niskiej jakości puli kompetencji aktorów angażujących się w debatę, po trzecie, ze sposobu prowadzenia rozmowy o wielokulturowości, to jest ukrywania jej pod płaszczykiem debat o zabytkach, wydarzeniach kulturalnych, wizerunku miasta itp. We Wrocławiu trudno odnaleźć tak duże otwarcie na nieoczywiste głosy w debacie i stymulowanie mieszkańców przez władze do wyrażenia swych opinii, jak ma to miejsce w Gdańsku. Dodatkowo, nie ma właściwie aktorów, którzy byliby, w efekcie refleksyjnego 
namysłu, zaakceptowani w roli inspiratorów lub liderów dyskusji, ponieważ wobec niemal każdej kategorii formułowane są zarzuty o inny od oczekiwanego sposób zaangażowania w debatę.

\section{WLĄCZANIE PERSPEKTYWY INNYCH}

Palimpsestowa figura ponowoczesnego miasta kwestionuje „samą postać konstruktora, posiadacza, tego «kto wie»" [Rewers 2005: 303]. Wskazuje to paradoksalnie - przy tożsamościowym boomie - na rozproszenie i nieciagłość tożsamości. Owo rozdarcie występuje od kilku dekad w naukach społecznych, znajduje także odbicie w dyskursach i narracjach poświęconych miastom - zwłaszcza tym z dziedzictwem kulturowym naznaczonym wpływami wielu różnych kultur. Przedmiotem zainteresowania od wielu lat jest nie tyle sam problematyczny materiał historyczny, ile jego konstrukcja narracyjna.

Sposób, w jaki budowano narracje tożsamościowe w Gdańsku powojennym, oparty był zasadniczo na konstrukcjach mitotwórczych, zwłaszcza na micie XVI-XVII-wiecznego ,złotego wieku”. W dyskursie publicznym na temat pamięci i tożsamości współczesnego Gdańska zdaje się dominować wieloparadygmatyczność, wykraczająca poza autentyzm dziedzictwa materialnego i kulturowego. Stosowane są w tym celu zakodowane już w samym języku metaforyczne wyobrażenia typu: Gdańsk jest miastem wielokulturowym, miastem wolności i miastem solidarności. Rozpoczęty wieki temu projekt tożsamościowy miasta wielu narodów, języków i religii, tradycji bałtyckich i hanzeatyckich, miasta Jana Heweliusza i Artura Schopenhauera, Güntera Grassa i Lecha Wałęsy, miasta dialogu i różnych wartości, mimo zasadniczej zmiany historycznej i politycznej, nie jest zakończony. Nie daje też tytułu, zdaniem niektórych historyków, do uznawania Gdańska za miasto-tygiel wielokulturowości [Loew 2003]. Samorządny Gdańsk do końca XVIII wieku niechętnie przyjmował obcych, którzy nie mieścili się w ściśle wyznaczonych ramach społecznych i religijnych. Mit dawnej wielokulturowości stał się jednak fundamentem narracji w polityce pamięci [Chwin 2014: 232]. Od przełomu lat 80. i 90. XX wieku w dyskusji o pamięci lokalnej swoje miejsce odzyskuje niemieckość, szczególnie mieszanina składników tworzących wielonarodowego ducha gdańskości. Ważną rolę w tych przemianach odegrały, zdaniem Stefana Chwina, kategoria pogranicza oraz funkcja mitu małej ojczyzny, polemicznej wobec dyskursu tożsamościowego ówczesnej władzy [Chwin 2014: 232].

Według Anthony’ego Giddensa [2014] we współczesnym dyskursie tożsamościowym odpowiedniejszym terminem, który oddaje fakt, że jako wspólnota 
ludzka weszliśmy w nową erę różnorodności, jest „międzykulturowość”. Chodzi w niej bardziej o procesy renegocjacji podzielanych tożsamości, które mogą odbudować sferę publiczną, o dialog. Posługiwanie się pojęciem wielokulturowości w zastępstwie „niemieckości” jest ideologizowaniem i mitologizowaniem pamięci. Dopiero w XIX stuleciu zaczęto konstruować niemiecką pamięć Gdańska i nigdy nie przybrała ona formy jednego spójnego systemu. Powstawały sprzeczne, niejednoznaczne narracje. Każda epoka, każda dominująca grupa społeczna miała swój interes, by pisać na nowo „gdańską księgę”, tak aby wynikało z niej, że to właśnie ta, a nie inna epoka lub zbiorowość tworzyła logiczny punkt docelowy dhugiej linii w rozwoju miasta. W budowaniu narracji mitotwórczych na temat wielokulturowości, polskości czy niemieckości wykorzystywano te same elementy. W dyskursie publicznym dopuszcza się jedynie nieliczne wydarzenia czy znaki pamięci, poddając je różnorodnej instrumentalizacji. Niewątpliwie w budowaniu tożsamości o polskich korzeniach jednym z najważniejszych rozdziałów było odwoływanie się do „złotego wieku”. Warto jednak podkreślić, że chociaż dziedzictwo tego okresu było dziełem zbiorowym, próbowano je przedstawiać w czasach deficytu tożsamości jako przynależne poszczególnym narodom albo mitycznemu wielokulturowemu społeczeństwu.

Mit wielokulturowego Wrocławia wypełnił lukę po zdezaktualizowanych wizerunkach miasta piastowskiego i lwowskiego. Jego wypracowanie i systematyczne upowszechnianie przez władze miasta miało na celu wzbudzenie społecznej energii oraz integrację wokół wartości takich jak otwartość i tolerancja (a więc niemających bezpośredniego związku z obiektywnym zróżnicowaniem etnicznym w mieście), które powinny zapewnić sukces w konfrontacji z nowoczesnymi wyzwaniami rozwojowymi miasta (reorientującego się na kulturę, turystykę jako ważne sektory usług). Władze, odpowiedzialne za kreację mitu, zdecydowały się na akcentowanie wątków prusko-niemieckich (mylnie zakładając, że inne wątki przedwojennej historii Wrocławia są mieszkańcom znane), co osłabiło znaczenie wątków czeskich i habsburskich oraz dopełniło podwójną deformację wielokulturowości Wrocławia, polegającą na utożsamieniu, po pierwsze, różnorodności etnicznej i kulturowej z wielokulturowością, a po drugie, tak rozumianej dawnej wielokulturowości z wielokulturowością współczesną. Niemniej na zawartość autostereotypu (jak dotychczas głównie deklaratywnego, bo pozbawionego większych możliwości konfrontacji) wrocławianina składa się przede wszystkim przekonanie o otwartości i tolerancji, co dowodzi, że w tej funkcji mit wielokulturowego Wrocławia się sprawdził. Mimo braku zróżnicowania etnicznego wrocławianie zdołali uzgodnić znaczenie pojęcia wielokulturowości z rzeczywistością społeczną poprzez poszukiwanie dowodów podtrzymujących tę zgodę 
w obszarze wielokulturowości nieetnicznej. Mit wielokulturowości Wrocławia nie został zdekonstruowany i nie zastępuje go żaden nowy mit, podlega raczej powolnemu rozmywaniu na skutek nadawania mu różnych znaczeń wydobywanych z rozmaitych sfer niezróżnicowanej etnicznie wrocławskiej rzeczywistości.

\section{WIELOKULTUROWOSĆ W ŚWIADOMOŚCI DYSKURSYWNEJ - WYZWANIA METODOLOGICZNE}

Przełożenie subtelnego i wysoce teoretycznego języka Giddensa na założenia modelu empirycznego pozwalającego uchwycić aspekty zjawiska wielokulturowości badanych miast w sposób inspirowany jego myślą nastręcza pewne trudności. Wynikają one przede wszystkim z faktu, że informacje pozyskane od badanych stanowią obraz tego, co potrafią oni powiedzieć o swoich działaniach, intencjach i motywach, a więc obraz świadomości dyskursywnej. Świadomość praktyczna, jej „oczywisty” charakter, który wyraża się raczej w zachowaniach i nie jest ujmowany w słowach, w badaniu pozostaje trudno uchwytna. Jej ślady lub raczej obrazy następcze (pojawiające się wówczas, gdy po wpatrywaniu się długo w jakiś kształt szybko odwracamy wzrok i przez chwilę pod powiekami widzimy go w barwie dopełniającej) mogą się ujawnić jako powidoki - „produkty uboczne" czujnego przyglądania się sposobom konstruowania wiedzy dyskursywnej. Zamiast o nieświadomości, w przypadku niniejszej analizy, należałoby raczej mówić o nie-świadomości jako rodzaju refleksyjnego i celowego odrzucenia pogłębionego, czasem bolesnego i wymagającego konfrontacji z utrwalonymi schematami myślenia i działania, sposobu konceptualizowania zagadnienia gdańskiej i wrocławskiej wielokulturowości.

Materiał empiryczny, który jest podstawą niniejszych rozważań, pozyskano w trakcie realizacji grantu Narodowego Centrum Nauki ${ }^{1}$, a do szczegółowej analizy wybrano treści z wywiadów swobodnych przeprowadzonych z ekspertami oraz dane pozyskane z wywiadów kwestionariuszowych z mieszkańcami Gdańska i Wrocławia (w liczbie, odpowiednio, 20 i 300 w każdym z miast). Badania kwestionariuszowe zostały przeprowadzone w maju 2015 roku na dobranej kwotowo próbie 300 mieszkańców w każdym z miast. Na kryterium doboru próby składały się: płeć, wiek i miejsce zamieszkania (10 okręgów w każdym $\mathrm{z}$ badanych miast). Celem wywiadów kwestionariuszowych było poznanie opinii

1 Projekt badawczy NCN nr 2013/09/B/HS6/00418 pt. „Tożsamość miasta i jego mieszkańców a przestrzeń publiczna. Studium trzech miast”. Zespół badawczy: Krzysztof Bierwiaczonek, Małgorzata Dymnicka, Katarzyna Kajdanek, Tomasz Nawrocki. 
mieszkańców dotyczącej tożsamości miast (ze szczególnym uwzględnieniem ich przeszłości), tożsamości mieszkańców oraz funkcjonowania przestrzeni publicznych. Dla prezentowanych poniżej rozważań istotnym elementem badań były wywiady swobodne przeprowadzone z ekspertami: lokalnymi politykami, urzędnikami miejskimi, dziennikarzami, architektami, historykami sztuki, aktywistami miejskimi. Warunkiem ich doboru było uznanie przez zespół badawczy, że są to osoby aktywne w tworzeniu debaty o mieście. Jednocześnie zadbano o to, by dobrać je w sposób zapewniający zróżnicowanie punktów widzenia, wynikające z ekspertyzy w określonej dziedzinie, zajmowanych stanowisk, możliwości wpływu na politykę pamięci, ale także sympatii politycznych.

Pogłębione wypowiedzi uzyskane w wywiadach służą do zarysowania bogatego tła dla wątków wielokulturowości. Z kolei wyniki badań ilościowych są interesującymi kontrapunktami dla tej opowieści i mają raczej za zadanie uświadomić konieczność formułowania kolejnych pytań, niż oferować jednoznaczne odpowiedzi.

Gdańsk we wczesnej nowożytności stał się miejscem wielokulturowym, łączącym tolerancję z dążeniem do wolności i do dobrobytu. Kulturowa rewolucja nastąpiła wówczas, gdy dorosła pierwsza generacja urodzonych w Gdańsku Polaków. Powojenne pokolenie gdańszczan budowało swoją tożsamość, nie tylko szukając polskich śladów w historii miasta, lecz także poszukując obcych źródeł. Pomostem do tych kultur i do innej perspektywy Gdańska, szczególnie jego niemieckiego i kaszubskiego oblicza, były książki Güntera Grassa, które wpisały miasto w uniwersalny pejzaż pamięci. Po 1989 roku mit wielokulturowego Gdańska czy mit tolerancji jego mieszczaństwa wzmacniał ducha otwartości. Jednakże mimo pozytywnej dynamiki polsko-niemiecki dialog w Gdańsku ma swoje ograniczenia. „Dla większości gdańszczan kultura niemiecka i protestancka pozostają nadal obce, co u jednych budzi ciekawość, u drugich obojętność, a w niektórych nawet rodzi lęk przed spotkaniem z innym" [Kerski 2014: 12].

W Gdańsku po 1945 roku nastapiła utrata nośników pamięci funkcjonalnej (tradycje, rytuały) i magazynującej (książki, obrazy, zbiory archiwalne, fotografie itp.). Dało to początek nowym opowieściom o Gdańsku, które budowano na mitach jego wielokulturowości, polskości i niemieckości. Stałą pozycję zajmuje w tej narracji historyczna i kulturowa symbolika osadzona w strukturze urbanistycznej i architektonicznej najstarszej, głównej części miasta. Agregacja zbioru cech podobnych umożliwia rozpoznawanie przez kolejne pokolenia mieszkańców znaków ciągłości i zarazem odrębności. W dyskursie narracyjnym ważne miejsce przypada jednak tym elementom (przedmiotom, symbolom, metaforom, mitom), które wzmacniaja poczucie przynależności do miasta [szerzej: Dymnicka, Szczepański 2016]. 
Stosunek do kultury niemieckiej, najdłużej obecnej w historii miasta, jest bardzo różny. Jak mówi jeden z ekspertów:

ostatnie pozytywne uczucia, to to, że nie jesteśmy po dwóch stronach wojennych od kilkudziesięciu lat, bo czas zatarł ślady. Złagodził negatywne relacje. Popularne wyjazdy na saksy, turystyka... Niemcy chwalą sobie Polaków.

W interpretacji problemów związanych z postrzeganiem obu miast w ciągłości czasu i przestrzeni ważną rolę odgrywa zdolność mieszkańców miast do refleksji. Obok systemu eksperckiego rozwijają się zdecentralizowane sieci aktywnych podmiotów, które organizują własne sfery i obiegi publiczne. W perspektywie teorii modernizacji refleksyjnej wzrastająca świadomość przestrzeni i miejsca jest w pierwszej kolejności nieodłączną częścią radykalnego wzmacniania indywidualizacji, w której aktorzy społeczni są coraz bardziej swobodni w budowaniu własnych narracji tożsamościowych.

Eksperci mają wystarczająco rozwiniętą świadomość istnienia wielu obrazów miasta z nakładającymi się na siebie epokami, symbolami i opowieściami. Twierdzą, że to nie tylko położenie nadmorskie i walor usytuowania miasta u ujścia Wisły przyczyniły się do wielonarodowościowego współżycia. Większość z nich podziela stanowisko historyków, że nie było przyjaźni, ale była tolerancja. Ślady w nazewnictwie, takie jak Stare i Nowe Szkoty, czy niderlandzkie wzorce architektoniczne to świadectwa ścierania się kultur. Jeszcze do początku lat 30. XX wieku relacje między poszczególnymi grupami narodów układały się w miarę poprawnie. Nagle jednak współistnienie Polaków i Danzigerów zostało brutalnie zakwestionowane i zniszczone. W świadomości dyskursywnej strażników pamięci i opinii ekspertów na temat znaczenia wielokulturowości w budowaniu współczesnej tożsamości miasta na plan pierwszy wysuwa się wątek problematyzacji tożsamościowej. Świadomość polskości i niemieckości Gdańska przeplata się z bezpieczniejszą konstrukcją wielokulturowości. Pokusa budowania wtórnej tożsamości jest w Gdańsku o wiele silniejsza niż na przykład w Gdyni - mieście wzniesionym w XX wieku, które w naturalny sposób sytuuje swoje mitologie w nowoczesności. W opinii ekspertów kładzie się zbyt mały nacisk na retorykę wielokulturowości w życiu codziennym. Kategoria wielokulturowości, co najczęściej podkreślaja, jest zmitologizowana. Jeden z nich zauważa:

[...] emigranci zawsze tu przyjeżdżali... na przykład studenci z zaprzyjaźnionych systemowo krajów, z Libii, z Nigerii. Dziś emigrantów także przybywa, przyjeżdżają do pracy, na studia, uciekają przed wojną jak Ukraińcy czy totalitaryzmem jak Białorusini, przed biedą i wykluczeniem jak rumuńscy Romowie. Ale obecność obcokrajowców jest u nas niemal niezauważalna, nie ma etnicznych dzielnic, o których marzyłabym, takich jak choćby w Londynie - z hinduskimi, chińskimi czy afrykańskimi świątyniami, sklepami, knajpkami, festi- 
walami. U nas najbardziej widoczni są Turcy, tureckie kebaby zdominowały rynek ulicznego jedzenia, i okey, to fajne. Ale gdzie inne nacje? Londyn to dla mnie miasto idealne, choć zabrzmi to banalnie, ale to miasto-świat w pigułce.

Niemiecka przeszłość miasta i jego dziedzictwo są gdańskie. I ten ponadnarodowy kwantyfikator stanowi o charakterze miasta. Niedostatki wiedzy historycznej dają znać o sobie w płytko zakorzenionej idei tożsamości budowanej na hasłach i sloganach. Wydaje się, że na jakiś mit założycielski miasta trzeba sięzdecydować i pozostać mu wiernym. Jeszcze w latach 90 . ubiegłego wieku z trudem przedostawała się do opinii publicznej wiedza, że w przeszłości dominowała kultura języka niemieckiego. Niektórzy z niedowierzaniem przyjmują do wiadomości, że w procesie sprawowania władzy przez wieki dominowali Niemcy. Ważną rolę w procesie odzyskiwania pamięci o wielokulturowości odegrały historiografia, literatura $\mathrm{i}$ architektura. To z nich powstają wciąż nowe opowieści, new urban myth, kwestionujące stare narracje mistrzowskie, albo, jak trafnie zauważa Peter Loew [2010: 439], przeobrażające Gdańsk - „przynajmniej w sferze kultury historycznej" - w Gdańzig. Może to znaczyć, że miasto jest na obiecującej drodze negocjowania różnych narracji. Nie da się ukryć, że pozostaje też w kręgu sprzecznych tendencji. Te ostatnie, zdaniem Chwina [2010: 45], można prześledzić na przykładzie recepcji albumów fotograficznych przedstawiających dawny Gdańsk jako zgodne miejsce współżycia wielu różnych nacji, także niemieckiej, oraz bezpieczny azyl dla dysydentów religijnych, unikając przy tym statystyk grup narodowościowych i religijnych. „Nowa pamięć opiera się na nowym sposobie czytania przestrzeni symbolicznej miasta. Tak jak podczas pierwszej reslawizacji Gdańska po roku 1945 spod nazw niemieckich wydobywano nazwy słowiańskie, by ujawnić prasłowiańskie korzenie miasta, tak teraz mamy do czynienia z tendencją odwrotną: spod nazw polskich wydobywa się nazwy obcojęzyczne, świadczące o obecności w Gdańsku różnych grup narodowościowych" [Chwin 2010: 45].

W świadomości dyskursywnej liderów pamięci i opinii rozpytywanych we Wrocławiu o sensy wielokulturowości zaznaczają się trzy wątki organizujące to, co i jak potrafią oni powiedzieć o swoich działaniach, intencjach i motywach, refleksyjnie wskazując na złożoność tej problematyki. Są to: świadomość niemieckości Wrocławia oraz tego, że jest ona poddawana zabiegom „symetryzacji”, tj. umniejszania znaczenia na rzecz uwypuklenia wielokulturowości; świadomość wykorzystywania hasła wielokulturowości w zabiegach marketingowych przez władze miasta; dominacja świadomości praktycznej nad urefleksyjnieniem wielokulturowości. Taka postawa jest charakterystyczna dla większości mieszkańców miasta.

Pierwszy aspekt świadomości dyskursywnej ujawniający się w opiniach liderów zasadza się na ich przekonaniu, że przedwojenny Wrocław był miastem 
w niemal stu procentach niemieckim, a we współczesnej opowieści o mieście symetryzuje się ten fakt, pokazując, że inne nacje były licznie reprezentowane, co uprawniałoby mówienie o wielokulturowości. Motywacją do takiego postępowania jest także chęć rozmywania dysproporcji poprzez wprowadzanie innych nacji, gdyż w dualnej strukturze ludnościowej przedwojennego miasta Polacy stanowiliby bardzo mały procent. Interesującym aspektem refleksji o symetryzacji niemieckości przeprowadzanej w taki właśnie sposób jest współczesne przepracowywanie mitu lwowskiego Wrocławia. Mniej więcej do lat 90. ubiegłego stulecia mówiono o grupie lwowskiej, że jest kośćcem miasta (a tworzyli ją nie tylko profesorowie uniwersyteccy, lecz także tramwajarze, artyści). Dziś lwowskość jest opisywana jako relikt, w dodatku liderzy pamięci wskazują na obserwowane przez siebie próby jej demitologizacji poprzez odwołanie do danych statystycznych obrazujących, ile faktycznie osób z rejonu Lwowa przyjechało do Wrocławia. Współcześnie symetryzacji podlegają też wątki żydowskie we Wrocławiu - ich „edytowanie" także stało się istotnym aspektem wiedzy dyskursywnej. Zauważa się swoistą modę na obecność motywów żydowskich w przestrzeni miasta, co - na wzór krakowskiego Kazimierza - miałoby się przekładać na sukces komercyjny restauracji i barów oraz przyciagać turystów. Jednocześnie komentuje się fakt, że istnieje znacząca dysproporcja pomiędzy wielkością „,sceny”, na której odgrywany jest spektakl wrocławskiej żydowskości (względnie duży kwartał ulic, imponująca synagoga, koszerne lokale), a wielkością i aktywnością gminy żydowskiej, która liczy nieco ponad stu członków, nie ma własnego rabina i pozostaje raczej pasywnym uczestnikiem życia społecznego i kulturalnego miasta.

Opisany wyżej punkt widzenia rewidujący sensy wielokulturowości we Wrocławiu do pewnego stopnia przenika do sposobu jej postrzegania przez mieszkańców, o czym zaświadczają dane pozyskane w badaniach własnych. Wobec zdecydowanej dominacji niemieckości w tkance miasta „odziedziczonego" po wojnie przez ludność polską połowa badanych wskazuje, że Wrocław był wówczas (w przeszłości) miastem bardziej niemieckim, a niemal 40\% jest skłonnych posłużyć się kalką „,wielokulturowości”, w której i tak największe znaczenie ma dialog pomiędzy polskością a niemieckością miasta. O Gdańsku jako mieście w przeszłości niemieckim myśli nieco ponad 1/4 badanych, a ponad połowa wybiera do jego opisu kategorię wielokulturowości, która - jak wynika ze studiów jakościowych - nie oznacza zwykłej mieszanki kultur, ale odmienną jakościowo danzigerskość. Zarazem jednak może zaskakiwać wysoki odsetek (nieco ponad 16\%) osób, które o współczesnym Wrocławiu są gotowe powiedzieć, że jest to niemieckie miasto (w Gdańsku takich odpowiedzi zanotowano o połowę mniej). Może to oznaczać, że wśród mieszkańców funkcjonuje 
uchwytna statystycznie kategoria, która opiera się próbom rozmycia znaczenia niemieckiego dziedzictwa w przestrzeni współczesnego Wrocławia. Jak zauważył jeden z rozmówców:

Za główną cechę wrocławskiej tożsamości uważam jednak zaakceptowanie przez mieszkańców niemieckiej przeszłości miasta, aprobatę dla jego dziedzictwa i nie tylko zgodę, ale i chęć jego kontynuowania, często w lekkiej opozycji do reszty kraju.

Zagospodarowywanie wielokulturowości na potrzeby marketingu miejskiego przez przedstawicieli lokalnej władzy to drugi istotny aspekt świadomości dyskursywnej, opisującej warunki tworzenia miejskiej refleksyjności, ujawniony w rozmowach z wrocławskimi ekspertami. W swoich opowieściach zwracają oni uwagę na to, że władze Wrocławia właściwie od początku transformacji prowadzą spójną i jednorodną politykę pamięci, której celem nie jest przepracowanie trudnych wątków z historii miasta (np. obecności w jego przestrzeni materialnych śladów obozów pracy przymusowej, porośniętych zielenią pagórków ruin niemieckiego miasta, zniszczonych cmentarzy, zabudowanych lub przemienionych na dzikie parkingi itd.), lecz przede wszystkim pozytywna mobilizacja mieszkańców wokół idei, że mieszkają w otwartym, tolerancyjnym mieście o wielowiekowej i złożonej historii, którą niekoniecznie trzeba szczegółowo znać. Trudna przeszłość Wrocławia jest w nim obecna, jakkolwiek paradoksalnie to brzmi, pod postacią pustek - dziur w zabudowie, nieoczywistych obszarów, na których nic nie powstaje, dzikich polan i niespodziewanych górek, zarosłych bujną zielenia, powstałych z ruin. One już wrosły w krajobraz miasta i nie są obiektami wymuszającymi myślenie o przeszłości czy konfrontację z nią - konieczność myślenia i zmagania się z dawnymi dziejami skutecznie zastapiły public relations i działania nakierowane na przestrzeń polegające między innymi na remontach kluczowych obiektów architektonicznych (np. ratusza i otoczenia rynku), które mają ułatwiać budowanie przywiązania i dumy z miasta.

Oddziaływanie władz na świadomość mieszkańców jest opisywane z dużym dystansem i sporą dozą krytycyzmu, które wynikają z przekonania ekspertów, że treści i wartości wykorzystywane do budowania przekazu są uproszczone, zbanalizowane i stanowią raczej odpowiedź władz na rodzaj mody na wielokulturowość niż odzwierciedlenie sposobów funkcjonowania miasta i życia jego mieszkańców. Jeden z rozmówców określa tę sytuację dosadnie, mówiąc, że mamy do czynienia z disneylandyzacją przestrzeni:

Jest disneyland, skansen - trzy ulice na krzyż i to jest dzielnica czterech kultur, i jedna taka, co nie umieją odbudować synagogi, nie ma rabina, nie ma gminy, mamy za to nazistów [...]. Jest wyobrażenie, że to jest miasto wielokulturowe [...]. Natomiast nie ma tej wielokulturo- 
wości ,żytej”, gdzie są sklepy japońskie, tureckie, inne kultury w obrazie miasta, w architekturze... ale wiemy, że trzeba być wielokulturowi, no to ludzie uważaja, że tak jest. Taka moda jest i ludzie to łyknęli.

Co więcej, rozmowy z samymi przedstawicielami władz sugerują wniosek o cynizmie, z jakim opracowują oni wrocławską przeszłość, upraszczając i banalizując przekaz historyczny (czego przykładem może być sukces wrocławskich krasnali), jak również zawłaszczając złożone treści historyczne dla celów marketingowych oraz po to, by mobilizować mieszkańców wokół korzystnego dla nich, ale wymyślonego autostereotypu.

Bardzo często przy różnych okazjach używaliśmy takiego argumentu, ciagu odwołań - to miasto zawsze było wielokulturowe, i dzisiaj też mamy efekt, czy też jesteśmy nosicielami tego, co było, bo dalej jesteśmy otwarci, wielokulturowi. Co oczywiście jest guzik prawda. Wrocław jest homogeniczny. Ilu tam jest tych zagranicznych czy migrantów. To nie jest odsetek, który mógłby wpłynąć na wizerunek miasta.

W przekonaniu rozmówców pracujących w urzędzie miasta historia sprzed 1945 roku, jako zasób treści kulturowych, z których mogliby czerpać, nie ma dla współczesnych wrocławian znaczenia. Jednocześnie władze nie widzą potrzeby, by tę sytuację zmieniać, bo w ich ocenie wiedza nie jest potrzebna, by poczuć się wrocławianinem i wyobrażać sobie, że enigmatyczna wielokulturowa przeszłość miasta promieniuje także na współczesność. Tym praktykom z niepokojem przyglądają się inni eksperci opisujący zabiegi marketingowe władz miasta jako przykład zagubienia i braku strategii oraz swoistej bezradności mieszkańców:

Wrocław to miasto, które chciałoby być wszystkim i często nie wie, w jakim kierunku ma zmierzać, wskutek czego rozprasza swe energie i pozwala na zbyt wiele swoim ambitnym władzom. Uważam to za negatywny wymiar wielokrotnej tożsamości.

W trakcie badania zapytano mieszkańców - w sposób otwarty - między innymi o charakterystyki, jakie można przypisać ich miastu. W przypadku Wrocławia do pierwszoplanowych cech (będących elementem narracji władz i refleksji ekspertów) zaliczono: otwartość, młodość, tolerancyjność. Paradoks tego autostereotypu polega na tym, że Wrocław w strukturze ludnościowej nie może wykazać znaczącego poziomu zróżnicowania etnicznego czy narodowego. Na takie cechy wskazało aż $38 \%$ badanych, o 14 punktów procentowych więcej niż w Gdańsku. Wprost o cesze wielokulturowości Wrocławia wypowiedziało się 14,2\% uczestników badań. Z jednej strony to dużo więcej niż w Gdańsku (4,5\%), ale $\mathrm{z}$ drugiej to względnie niskie wskazanie, jeśli wziąć pod uwagę wieloletnią konsekwencję, z jaką wielokulturowość Wrocławia była promowana przez władze. Może to dowodzić, że wiedza praktyczna mieszkańców i jej „oczywistość” 
dotyczą raczej szeroko akceptowanego autostereotypu mieszkańca niż kwestii wielokulturowości, która pozostaje nierozwikłaną enigmą, szczególnie wobec braku zachęt i wsparcia, by się z tą tajemnicą mierzyć.

\section{PODSUMOWANIE}

We współczesnych narracjach miejskich obecne są elementy tożsamości jeszcze do niedawna uznawane za nie swoje dziedzictwo. Model tygla, przez lata uważany za inspirujący i mitotwórczy, ustępuje obrazowi miasta złożonemu z wielu części o charakterze amalgamatu. Skład tej mieszaniny zmieniał się bowiem w różnych okresach i w żadnym z nich miejskie społeczności nie budowały swojej tożsamości od zera. Zawsze istniały pozostałości tego, czego się w tyglu przetopić nie dało. W przypadku Gdańska dziedzictwo „obcych” odgrywało rolę „włączającą”. Wciąż przepracowywane jest fundamentalne dla gdańskiej tożsamości pytanie o stosunek dziedziczących do dziedziczonego. Tradycja i dziedzictwo pozostawały bowiem przez wieki $\mathrm{w}$ istotnej dynamicznej zależności. Taka postawa pozwalała łączyć w sobie różne wymiary pamięci i historii. Dawny Gdańsk trwa w dużej mierze w murach, ale staje się coraz bardziej obecny w świadomości gdańszczan i w miejskich opowieściach.

Dla wrocławskiego sposobu opracowywania wielokulturowych elementów tożsamości miasta i jego mieszkańców charakterystyczne jest pęknięcie pomiędzy świadomością dyskursywną tych (ekspertów i mieszkańców), którzy widzą i trafnie odczytują nawiązania (także w postaci pustki, nieobecności) do innych kultur, rozumiejąc złożoność kontekstów społecznych i przestrzennych, współczesnych i historycznych tego dziedzictwa, a tych, dla których jest ono transparentne, niewidzialne ze względu na brak kompetencji. O odmienności przypadku wrocławskiego zaświadcza i to, że o ile w Gdańsku brak wiedzy został zdiagnozowany jako deficyt wymagający wieloaspektowego uzupełnienia, o tyle we Wrocławiu jest on traktowany jako ułatwienie - względnie niski poziom i zasięg myślenia refleksyjnego ułatwiają zarządzanie wizerunkiem miasta, bo nie generują negatywnych emocji i skutecznie zniechęcają do otwartego stawiania pytań o trudną przeszłość miasta.

\section{BIBLIOGRAFIA}

Alexander Jeffrey. 2010. Znaczenia spoteczne. Studia z socjologii kulturowej, przeł. S. Burdziej, J. Gądecki. Kraków: Zakład Wydawniczy Nomos.

Bauman Zygmunt. 2003. Razem, osobno, przeł. T. Kunz. Kraków: Wydawnictwo Literackie. 
Bauman Zygmunt. 2007. Tożsamość. Rozmowy z Benedetto Vecchim, przeł. J. Łaszcz. Gdańsk: Gdańskie Wydawnictwo Psychologiczne.

Beck Ulrich. 2016. Modernizacja refleksywna. Szkic pewnego argumentu. W: Przesilenie. Nowa kultura polityczna, J. Kołtan (red.), 41-63. Gdańsk: Europejskie Centrum Solidarności.

Beck Ulrich, Edgar Grande. 2009. Europa kosmopolityczna. Społeczeństwo i polityka drugiej nowoczesności, przeł. A. Ochocki. Warszawa: Wydawnictwo Naukowe Scholar.

Bierwiaczonek Krzysztof, Małgorzata Dymnicka, Katarzyna Kajdanek, Tomasz Nawrocki. 2017. Miasto, przestrzeń, tożsamość. Studium trzech miast: Gdańsk, Gliwice, Wrocław. Warszawa: Wydawnictwo Naukowe Scholar.

Binnie Jon, Jukian Holloway, Steve Millington, Craig Young. 2006. Conclusion: the paradoxes of cosmopolitan urbanism. In: Cosmopolitan urbanism, J. Binnie, J. Holloway, S. Millington, C. Young (eds.), 246-254. London, New York: Routledge.

Burszta Wojciech Józef. 1998. Antropologia kultury. Poznań: Wydawnictwo Zysk i S-ka.

Czumalo Vladimir. 2012. „Potrzeba identyfikacji?” Autoportret 1: 46-52.

Chwin Stefan. 2010. „Mity i prawdy nowej gdańskiej pamięci”. Przeglad Polityczny 102: 41-48.

Chwin Stefan. 2014. Mity i prawdy nowej gdańskiej pamięci. W: Gdańskie tożsamości. Eseje o mieście, B. Kerski (red.), 223-241. Gdańsk: Instytut Kultury Miejskiej.

Clifford James. 1992. „Samokreacja etnograficzna: Conrad i Malinowski”, przeł. M. Krupa. Konteksty 3-4: 10-18.

Dymnicka Malgorzata. 2017. The urbanity phenomenon - tradition and new cultural iterations. In: Re-imaging the city. City and urban today from the sociological perspective, M. Smagacz-Poziemska, K. Frysztacki, A. Bukowski (eds.), 13-32. Kraków: Jagiellonian University Press \& Polish Academy of Sciences.

Dymnicka Małgorzata, Jakub Szczepański. 2016. „Polityka pamięci i tożsamości wobec (nie) chcianego dziedzictwa. Od Gdańska do Gdańzigu". Przegląd Socjologiczny LXV/1: 81-100.

Giddens Anthony. 2001. Nowoczesność i tożsamość, przeł. A. Szulżycka. Warszawa: Wydawnictwo Naukowe PWN.

Giddens Anthony. 2003. Stanowienie społeczeństwa. Zarys teorii strukturacji, przeł. S. Amsterdamski. Poznań: Wydawnictwo Zysk i S-ka.

Giddens Anthony. 2014. Europa burzliwy i potężny kontynent. Warszawa: Wydawnictwo Naukowe PWN.

Golka Marian. 2010. Imiona wielokulturowości. Warszawa: Warszawskie Wydawnictwo Literackie MUZA SA.

Haydn Florian, Robert Temel (eds.). 2006. Temporary urban spaces: concepts for the use of city spaces. Basel: Birkhauser.

Kerski Basil. 2014. Gdańskie tożsamości. Wstęp do antologii. W: Gdańskie tożsamości. Eseje o mieście, B. Kerski (red.), 7-14. Gdańsk: Instytut Kultury Miejskiej.

Kowalski Krzysztof. 2013. O istocie dziedzictwa europejskiego - rozważania. Kraków: Międzynarodowe Centrum Kultury.

Krajewski Marek. 1997. Paradoksy wielokulturowości. W: Teorie społeczne a możliwości praktyczne, R. Cichocki (red.), 23-33. Poznań: Wydawnictwo Media-GT.

Krzysztofek Kazimierz. 2005. Tendencje zmian w przestrzeni późnonowoczesnego miasta. W: Przemiany miasta. Wokól socjologii Aleksandra Wallisa, B. Jałowiecki, A. Majer, M.S. Szczepański (red.), 37-52. Warszawa: Wydawnictwo Naukowe Scholar. 
Loew Peter Oliver. 2003. Niemieckość - polskość - wielokulturowość? Gdańsk i jego mity. W: Tożsamość miejsca i ludzi. Gdańszczanie $i$ ich miasto $w$ perspektywie socjologicznej, M. Dymnicka, Z. Opacki (red.), 107-118. Warszawa: Oficyna Naukowa.

Loew Peter Oliver. 2010. Gdańsk i jego przeszłość, tłum. J. Mosakowski. Gdańsk: Wydawnictwo słowo/obraz terytoria.

Loew Peter Oliver. 2013. Gdańsk. Biografia miasta, przeł. J. Górny. Gdańsk: Instytut Kultury Miejskiej.

Marody Mirosława, Anna Giza-Poleszczuk. 2004. Przemiany więzi społecznych. Zarys teorii zmiany społecznej. Warszawa: Wydawnictwo Naukowe Scholar.

Mucha Janusz. 1999. „Wielokulturowość etniczna i nieetniczna”. Sprawy Narodowościowe 14-15: 41-51.

Nora Pierre. 2010. „Dziedzictwo”. Przegląd Polityczny 103/104: 234-236.

Obracht-Prondzyński Cezary. 2011. Gdański fenomen jako wyzwanie badawcze. W: Gdański fenomen, L. Michałowski (red.), 12-29. Warszawa: Wydawnictwo Naukowe Scholar.

Rewers Ewa. 2005. Post-Polis. Wstęp do filozofii ponowoczesnego miasta. Kraków: Universitas.

Robbins Bruce. 1998. Comparative cosmopolitanism. In: Cosmopolitics, P. Cheah, B. Robbins (eds.), 246-265. Minneapolis: University of Minnesota Press.

Sadowski Andrzej. 2011. Społeczeństwo polskie - od zróżnicowanego kulturowo do wielokulturowego. Szanse i zagrożenia. W: Wielokulturowość: konflikt czy koegzystencja, A. Śliz, M.S. Szczepański (red.), 48-73. Warszawa: Wydawnictwo Instytutu Filozofii i Socjologii PAN

Szacki Jerzy. 2001. „Historia i mitologia”. Res Publica Nowa 7: 53-57.

Szahaj Andrzej. 2010. Wielokulturowość: za i przeciw. W: Studia nad wielokulturowościa, D. Pietrzyk-Reeves, M. Kułakowska (red.), 25-30. Kraków: Księgarnia Akademicka.

Śliz Anna, Marek Stanisław Szczepański. 2011. „Wielokulturowość i jej socjologiczny sens. Festival Caravan czy wielokulturowe Street Party?” Studia Socjologiczne 4: 7-25.

Welsh Wolfgang. 2004. Tożsamość w epoce globalizacji - perspektywa transkulturowa, przeł. K. Wilkoszewska. W: Estetyka transkulturowa, K. Wilkoszewska (red.), 31-43. Kraków: Universitas.

Wieviorka Michel. 2011. Dziewięć wykładów z socjologii, przeł. A. Trąbka. Kraków: Zakład Wydawniczy Nomos.

Matgorzata Dymnicka

Katarzyna Kajdanek

\section{THE ROLE OF MULTICULTURAL INTANGIBLE HERITAGE IN THE CONSCIOUSNESS OF URBAN ACTORS. THE CASE OF GDANSK AND WROCLAW}

\footnotetext{
Abstract

The aim of the article is to present a conceptual and interpretative framework for most current discourse on the role of multicultural intangible heritage in the process of meaning-making and shaping the identity of the cities of Gdansk and Wroclaw. The focus is on the analysis of various
} 
forms of presenting patterns of identity of cities with a multicultural past, exhibited by expert and lay informants from both cities. The conceptual framework uses some elements of a multidimensional concept of modernity, including Anthony Giddens' theory of structuration, which emphasizes the role of types of knowledge used by various actors of social life and points to active and reflexive individuals. A key word is discursive knowledge - knowledge that can be verbalized and practical - more difficult to express verbally but decisive when it comes to taking action. The focus is on reflexive individuals in their social actions around discursive and practical codes constitutive for urban identity. Empirical data for the analysis was drawn from semi-structured interviews with expert informants and survey questionnaires with lay inhabitants of the two cities. The analysis is focused on a variety of models of reflexivity rooted in social practices, in the potential of production and reproduction of cityness in the context of multiculturalism.

Keywords: multiculturalism, identity, intangible heritage, Gdansk, Wroclaw 